\title{
OMEJEVANJE KRAŠKIH KOTANJ Z ANALIZO POLREZOV
}

Izvirni znanstveni članek COBISS 1.01

DOI: 10.4312/dela.53.5-22

\section{Izvleček}

Razvoj metod daljinskega zaznavanja, računalnikov in programske opreme za obdelavo prostorskih podatkov se je dotaknil tudi področja geomorfologije. Vse troje omogoča hitrejšo analizo večjih količin podatkov, ne pa tudi natančnejše. Vzrok za to je slaba matematična definiranost nekaterih geomorfoloških oblik. V raziskavi se osredotočamo na omejevanje kraških kotanj. Za ta namen smo razvili nov pristop, ki pri določanju roba kotanje analizira njene polreze ter učinkovito zaznava tudi robove kotanj na pobočjih. Metoda omogoča pridobivanje natančnejših morfografskih in morfometričnih podatkov o kotanjah. Metodo smo razvili in preizkusili na petih kotanjah Podgrajskega podolja (JZ Slovenija) ter rezultate primerjali z rezultati metode, ki za omejevanje kotanj uporablja hidrološko modeliranje. Opažamo bistveno izboljšanje rezultatov pri omejevanju z novo metodo.

Ključne besede: kraške kotanje, samodejno omejevanje, GIS, polrez, geomorfologija

* Inštitut za antropološke in prostorske študije, Znanstveno raziskovalni center Slovenske akademije znanosti in umetnosti, Novi trg 2, SI-1000 Ljubljana; Oddelek za geografijo, Filozofska fakulteta, Univerza v Ljubljani, Aškerčeva ulica 2, SI-1000 Ljubljana; Slovenski center odličnosti za vesoljsko znanost in tehnologije, Aškerčeva ulica 12, SI1000 Ljubljana

e-pošta: ales.grlj@zrc-sazu.si 


\section{KARST DEPRESSION DELINEATION USING HALF-SECTION ANALYSIS}

\section{Abstract}

The development of remote sensing methods, computers and spatial data processing software has also affected the field of geomorphology. All three allow for faster analysis of larger amounts of data, but not more accurate. The reason for this is the poor mathematical definition of some geomorphological forms. The research focuses on the delimitation of karst depressions. For this purpose, we have developed a new approach that analyzes its half-sections when determining the edge of a depression and also effectively detects the edges of depressions on slopes. The method allows obtaining more accurate morphographic and morphometric data on depressions. The method was developed and tested on five depressions of the Podgrajsko podolje (SW Slovenia), and the results were compared with the results of a method that uses hydrological modeling to delimit the depressions. We observe a significant improvement in the results obtained with the new method.

Keywords: karst depressions, automatic delineation, GIS, half-section, geomorphology

\section{UVOD}

Kotanje navadno razumemo kot vbočene oblike nekega površja. Gre za del površja, ki je $\mathrm{v} v$ seh smereh, glede na izhodišče $\mathrm{v}$ dnu, nižji od površja, na katerem se nahaja. Najdemo jih praktično na vseh površinah ter jih dojemamo kot anomalije ali suboptimalno stanje na idealno ravni oziroma gladki površini. $V$ tem smislu jih obravnavamo kot območja, kjer je snov na površju bolj izpostavljena obrabi, koroziji ali pa odraža mesta nezveznosti, šibkosti snovi ter je zaradi tega tudi bolj izpostavljena obema navedenima in še drugim procesom. V geomorfologiji se pogosto ukvarjamo s kotanjami v zemeljskem površju. Slednje se lahko pojavljajo na različnih tipih površja ter obsegajo različne velikostne razrede (Gabrovšek, Stepišnik, 2011; Sauro, 2012; Stepišnik, 2015; Stepišnik, 2017; Šušteršič, 1986; Waltham, Bell, Culshaw, 2010). Kot take lahko obravnavamo vulkanske kaldere, kotanje za čelnimi morenami nekdanjih ledenikov, zaprte nižine med sipinami ali endoreična porečja. Kotanje so tipične in zelo pogoste, po nekaterih avtorjih tudi indikativne, oblike kraškega reliefa (Ford, Williams, 2007; Sweeting, 1972; Waltham, Fookes, 2003). Izraz kraške kotanje tako označuje kotanje, ki se pojavljajo na kraškem tipu reliefa (Obu, 2011). Pri nas se za kraške kotanje največkrat štejejo vrtače, udornice, uvale, kraška polja, slepe doline in konte (Obu, 2011). V splošnem gre za mesta hitrejšega oziroma močnejšega raztapljanja in odnašanja 
kraških kamnin. Vzrok za to je povečan vtok ali infiltracija vode, ki je navadno posledica nezveznosti v kraških kamninah. Na podlagi dimenzij, razporeditve in odnosov med kraškimi kotanjami na površju lahko torej sklepamo na oblike in procese, ki se odvijajo v podzemlju (Vrviščar, 2016). Iz tega dejstva izhaja potreba po geomorfološki analizi kraških kotanj. S tem se je ukvarjalo več avtorjev, navedenih v nadaljevanju. Večinoma gre bodisi za terensko preučevanje oblike ali pa za analizo razporeditve in morfometrije na podlagi topografskih kart. Analize na podlagi slednjih so a priori podvržene slabšim rezultatom zaradi kakovosti vira zajema podatkov ter subjektivnosti dojemanja obsega kotanje (slika 1). Razvoj metod daljinskega zaznavanja, računalnikov ter programske opreme $\mathrm{v}$ zadnjih desetletjih geomorfologom omogoča obdelavo podatkov na večjih območjih. Tako kot druge površinske oblike so tudi kotanje dočakale metode, s katerimi jih lahko samodejno prepoznamo in omejimo.

$\mathrm{Z}$ razvijanjem metod za samodejno prepoznavanje reliefnih oblik se je ukvarjalo več avtorjev, med njimi Krevs (1992) ter Podobnikar in Možina (2008). Pri delu Obuja (2011) gre za popolnoma avtomatiziran postopek zaznavanja kotanj na podlagi digitalnega modela višin (DMV). Podoben pristop $\mathrm{z}$ iterativnim zapolnjevanjem kotanj DMV in odštevanjem izvornega DMV od zapolnjenega je opisan v objavi Grlja in Grigilla (2014). Slednji pristop je uporabila tudi Novljan (2019), ki se je ukvarjala z zaznavanjem in morfometrijo vrtač na pobočjih. Nekoliko drugačno morfometrično analizo vrtač, ki temelji na izračunih s pomočjo DMV s prostorsko ločljivostjo enega metra, izdelanega iz podatkov lidarskega snemanja, je na Menišiji opravil Mihevc (2014). Vrtače je iz modela površja zaznaval z izračunom indeksa konkavnosti površja $\mathrm{v}$ treh različnih merilih, podatke pa je nato med seboj prekril in uporabil tiste, ki so bili bolj natančni. Iz podatkov je nato izločil zaznane kotanje, ki niso vrtače, izmed preostalih zaznanih vrtač pa je izračunal površino, globino in polmer povprečne vrtače na preučevanem območju (Mihevc, 2014). Nabor tuje literature s področja avtomatiziranega zaznavanja kraških kotanj je nekoliko večji. Rahimi in Alexander (2013) sta primerjala rezultate različnih metod kartiranja in zaznavanja vrtač v Minnesoti. V programu MATLAB sta razvila algoritem, ki $\mathrm{v}$ treh korakih samodejno prepozna vrtače, ter rezultate primerjala $\mathrm{z}$ drugimi pristopi $\mathrm{k}$ rešitvi problema. Podobno kot prejšnja raziskava tudi prispevek Doctorja in Younga (2013) primerja več načinov zaznave kraških kotanj. Prvi način je ročno kartiranje kotanj na podlagah, izdelanih iz DMV (osenčenost reliefa, osenčenost naklonov, indeks topografskega položaja), ter na letalskih posnetkih. Drugi način temelji na obdelavi DMV: od zapolnjevanja kotanj, odštevanja hidrološko pravilnega modela reliefa od originalnega modela do končne vektorizacije kotanj. Nekoliko drugačen pristop k samodejnemu zaznavanju kraških kotanj sta razvila Liang in Du (2013). Način, opisan v raziskavi, temelji na prepoznavanju petih običajnih površinskih kraških pojavov: osamljenih hribov, osamljenih vrtač, gruč hribov, gruč vrtač ter gruč hribov z vrtačami, na podlagi sklenjenih plastnic. Guimarães in sodelavci (2005) so pri obdelavi modela reliefa uporabili isto metodo kot Doctor in Young (2013), iz satelitskega posnetka pa so izračunali 
normirani diferencialni vegetacijski indeks (NDVI). Tri različne načine zaznavanja vrtač je primerjal Bauer (2015). Preučevano območje je analiziral z že predstavljenima metodama skrajne sklenjene plastnice $\mathrm{z}$ ekvidistanco enega metra in zaznavanja vrtač s pomočjo izdelave hidrološko pravilnega reliefa ter $\mathrm{z}$ metodo določanja porečja, pri čemer vsaka kotanja predstavlja svoje porečje. Preizkušene metode so dale različne rezultate tako po morfometriji vrtač kot tudi po njihovem številu (Bauer, 2015). Podobno primerjavo so naredili tudi Telbisz in sod. (2016), pri čemer so se osredotočili predvsem na prednosti DMV-ja, izdelanega iz podatkov lidarskega snemanja, v primerjavi s topografskimi kartami. Primerjali so rezultate omejevanja vrtač s pomočjo topografske karte 1:10.000, pri čemer so uporabili metodo skrajne sklenjene plastnice, vrtač, zaznanih iz digitaliziranih plastnic DMV-ja, ter vrtač, zaznanih iz DMV-ja s pomočjo izdelave hidrološko pravilnega porečja. Ugotovili so, da so vrtače, zaznane $\mathrm{z}$ avtomatiziranimi metodami, po površini večje od tistih, zaznanih s klasičnimi metodami (Telbisz in sod., 2016).

Slika 1: Primeriava profilov kotanj na ravnini in na pobočju.

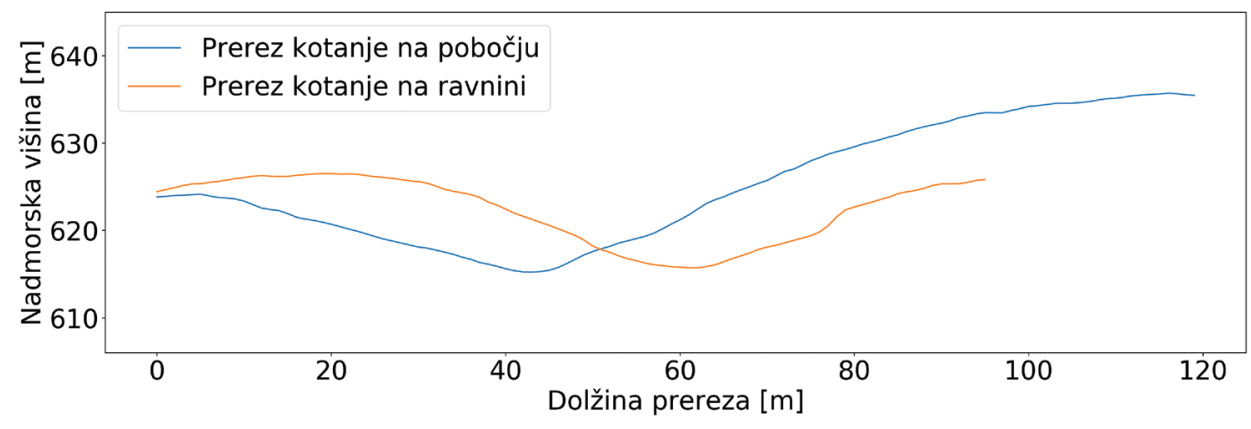

Vse navedene metode omejevanja kotanj imajo različne pomanjkljivosti. Ročen zajem z digitalizacijo obodov iz DMV, topografskih kart in slikovnih podob površja je zamuden in subjektiven. Samodejne metode odpravijo te pomanjkljivosti, vendar vpeljejo nove. Modeliranje oboda kotanj s hidrološkim zapolnjevanjem omeji kotanjo na plastnico, ki povezuje točke $\mathrm{z}$ isto višino, kot je višina najnižje točke oboda. Ta pristop deloma deluje na uravnavah, odpove pa na pobočjih in pri kotanjah $\mathrm{z}$ razčlenjenim obodom, kjer definicija kotanje z najnižjo točko oboda ni več ustrezna. Najbolj realistično obod kotanje opišejo metode zaznavanja z izračunom konkavnosti in povprečevanjem DMV s konvolucijo. Ta pristop vselej nekoliko podceni površino in globino kotanje ter je zelo odvisen od oblike in velikosti obravnavanega sosedstva.

$\mathrm{V}$ članku predstavljamo novo metodo določanja skrajnih točk oboda kotanje na podlagi analize polrezov. Polrez je višinski profil kotanje, ki ga definirata središče kotanje ter točka na obodu kotanje. Polrez kotanje lahko obravnavamo kot trend v vrsti podatkov 
o višinah, kotanjo pa kot anomalijo $\mathrm{v}$ tem trendu. $\mathrm{Z}$ uporabo linearne regresije trend pobočja odstranimo ter določimo vrhove nove funkcije. Ti vrhovi ustrezajo lokacijam skrajnih točk kotanj. Namen raziskave je razvoj nove in natančnejše metode zaznavanja obodov kotanj. Z natančnejšimi podatki o kotanjah bomo lahko v prihodnosti natančneje morfografsko in morfometrično opisali značilnosti kraških kotanj.

\section{OBRAVNAVANO OBMOČJE IN UPORABLENI PROSTORSKI PODATKI}

Kotanja je lahko kateri koli objekt v rastrskih podatkih, ki ima vrednosti slikovnih točk nižje od svoje okolice. Na infrardečem kanalu satelitske podobe ali podatkih radarskega skeniranja je to lahko vodna površina. V podatkih o nadmorskih višinah so to lahko kraške kotanje, kot so vrtače ali udornice. Slednje smo si tudi izbrali za testiranje razvite metode. Obravnavane kotanje se nahajajo na Podgrajskem podolju. Podgrajsko podolje je kraška uravnava med Brkini na severovzhodu in pogorjem Slavnika na jugozahodu. Sestavljeno je iz apnencev, dolomitov in breče obeh kamnin. Kamnine so v celoti kredne starosti. Podolje je splošno gledano uravnava, vendar je $\mathrm{v}$ grobem razdeljeno na dva dela. Severozahodni del v smeri Kozine je bolj uravnan in nižji. Jugovzhodni del v smeri Staroda je dvignjen in vertikalno bolj razčlenjen. Oba dela zaznamuje velika gostota kraških kotanj, predvsem vrtač. Vzdolž stika z nekraškimi kamninami Brkinov se oblikuje niz slepih dolin, ki velja za najlepši primer kontaktnega krasa $\mathrm{v}$ tem delu sveta. $\mathrm{V}$ zaledju ponorov $\mathrm{v}$ slepih dolinah ob in na presečiščih prelomov in pretrtih kamnin se nahajajo udornice, ki na površini nakazujejo podzemni tok vode.

Za razvoj in preverjanje rezultatov metode smo si izbrali nabor kotanj, ki se nahajajo v jugovzhodnem delu Podgrajskega podolja. Kot je že bilo navedeno, je ta del podolja vertikalno bolj razčlenjen. To pomeni, da se kraške kotanje tu pojavljajo na neravni površini in njihovi obodi niso $\mathrm{v}$ vodoravni ravnini, temveč so $\mathrm{v}$ ravnini pobočja, na katerem se nahajajo. Poleg tega so obodi izbranih kotanj dodatno razčlenjeni in lokalno odstopajo od ravnine pobočja. Na takem površju so dejanski obodi kraških kotanj, kot jih dojame človek, najbolj različni od hidrološko modeliranih obodov. Kot take jih je tudi veliko težje samodejno računalniško modelirati.

\section{METODOLOGIJA}

V nadaljevanju opisan pristop modeliranja oboda kraških kotanj obsega dva sklopa. V prvem sklopu je opisan že znan pristop, ki temelji na hidrološkem modeliranju oboda kotanj. Pristop omeji kotanjo z zaprto plastnico, katere nadmorska višina ustreza višini najnižje točke oboda. Drugi sklop opisuje nadgradnjo hidrološkega modela. S 
prvim sklopom iz DMV prepoznamo zaprte konkavne oblike, kotanje $\mathrm{v}$ hidrološkem smislu, ki bi ob simuliranju vodnega toka preko DMV delovale kot ponori oziroma ojezeritve. Rezultati tega modeliranja so vhodni podatek za drugi metodološki sklop. V slednjem zgolj popravimo vhodne obode glede na DMV, tako da upoštevajo naklon pobočja ter rob kotanje postavijo na mesta pregiba pobočja v kotanjo. Pregibi se določajo na profilih polrezov površja med središčem hidrološke kotanje in točko, ki jo določata kot (azimut) med središčem in izbranim ogliščem oboda kotanje ter večkratnik razdalje med središčem in izbranim ogliščem.

Za izvedbo analize v prvem sklopu smo uporabili program, ki smo ga razvili $\mathrm{v}$ predhodni raziskavi (Grlj, Grigillo, 2014). Napisan je v programskem jeziku Python in uporablja orodja knjižnice ArcPy, ki jo za namen avtomatizacije opravil v programu ArcGIS razvija Environmental Systems Research Institute (ESRI). Tako kot prvi je tudi drugi metodološki sklop izveden v programskem jeziku Python. Za razliko od prvega uporablja izključno brezplačne knjižnice.

Edini vhodni podatek je DMV obravnavanega območja v prostorski ločljivosti 1 $\mathrm{m}$ (Lidar ARSO, 2014). Izdelan je bil z interpolacijo vektorskih podatkov laserskega snemanja Slovenije iz klasificiranega oblaka točk. Uporabljene so bile samo talne točke. Podatke smo interpolirali po metodi najbližjega soseda (ang. nearest neighbour).

\subsection{Hidrološko modeliranje oboda kotanj}

Za modeliranje hidrološko pravilnih obodov kotanj smo izbrali v predhodnih raziskavah razvito metodo (Grlj, Grigillo, 2014). Metoda temelji na uporabi orodij za izdelavo hidrološko pravilnega DMV za izračun redov vodnih tokov in porečij. Slika 2 prikazuje konceptualni model tega pristopa. Temeljno orodje je orodje Fill, ki je v osnovi namenjeno odstranjevanju (zapolnjevanju) majhnih kotanj v DMV, ki onemogočajo nemoteno simulacijo vodnega toka. Od rezultata tega orodja odštejemo prvotni DMV, da dobimo podatek, kje se zmanjševanec in odštevanec razlikujeta. Slikovne točke, ki imajo po odštevanju vrednost različno od 0 , predstavljajo kotanje.

Po tem se vrednosti razlike pretvorijo $\mathrm{v} 1 \mathrm{za}$ vse vrednosti različne od 0 in 0 za vse vrednosti enake 0 . rastrski sloj s takimi kategoričnimi vrednostmi celih števil enostavno pretvorimo v vektorski sloj poligonov, ki predstavljajo površine kotanj. Orodju Fill lahko s parametrom $z$-limit omejimo globino zapolnjevanja. To pomeni, da bodo zapolnjene samo kotanje $\mathrm{z}$ globino, manjšo od vrednosti tega parametra. $\mathrm{Z}$ iteracijo opisanega postopka in večanjem vrednosti parametra $\mathrm{z}$-limit $\mathrm{v}$ vsaki ponovitvi lahko s programom zaznamo kotanje vseh redov oziroma gnezdene kotanje. Rezultat hidrološkega modeliranja je, poleg DMV, vhodni podatek drugega koraka omejevanja kotanj. 
Slika 2: Konceptualni model omejevanja kotanj s hidrološkim modeliranjem (Grlj, Grigillo, 2014).

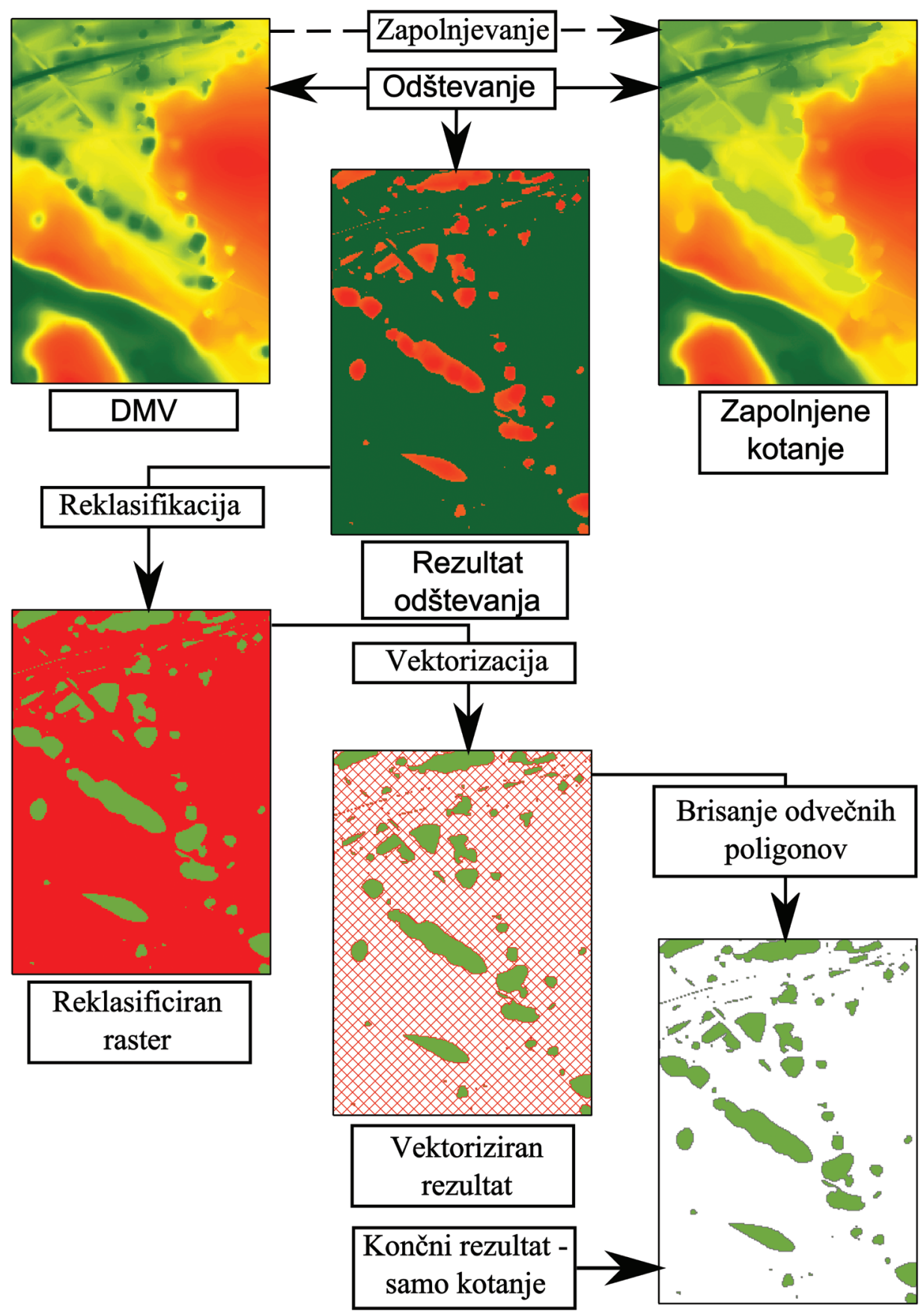




\subsection{Modeliranje oboda kotanj s polrezi}

Vektorski sloj, ki ga smo ga pridelali v prvem koraku obdelave podatkov, uporabimo za določitev središča poligona kotanje. Oblika poligona kotanje zaradi izvora v rastrskem sloju nima idealnih robov za nadaljnjo analizo. Pomanjkljivosti odpravimo z izračunom minimalne oklepajoče geometrije oziroma konveksne ovojnice. S tem odpravimo nazobčane robove oboda in vbokline na obodu. Z zgostitvijo oglišč na geometriji oboda odpravimo primanjkljaj oglišč na daljših ravnih odsekih oboda. $S$ tem zagotovimo zadostno število oglišč za določitev poteka daljic polrezov. Z določitvijo centroida tako pripravljenega poligona oboda kotanje imamo na voljo dovolj podatkov za izvedbo analize.

Slika 3: Vzorčna kotanja, uporabljena za razvoj metode s polrezi ter konveksno ovojnico geometrije.

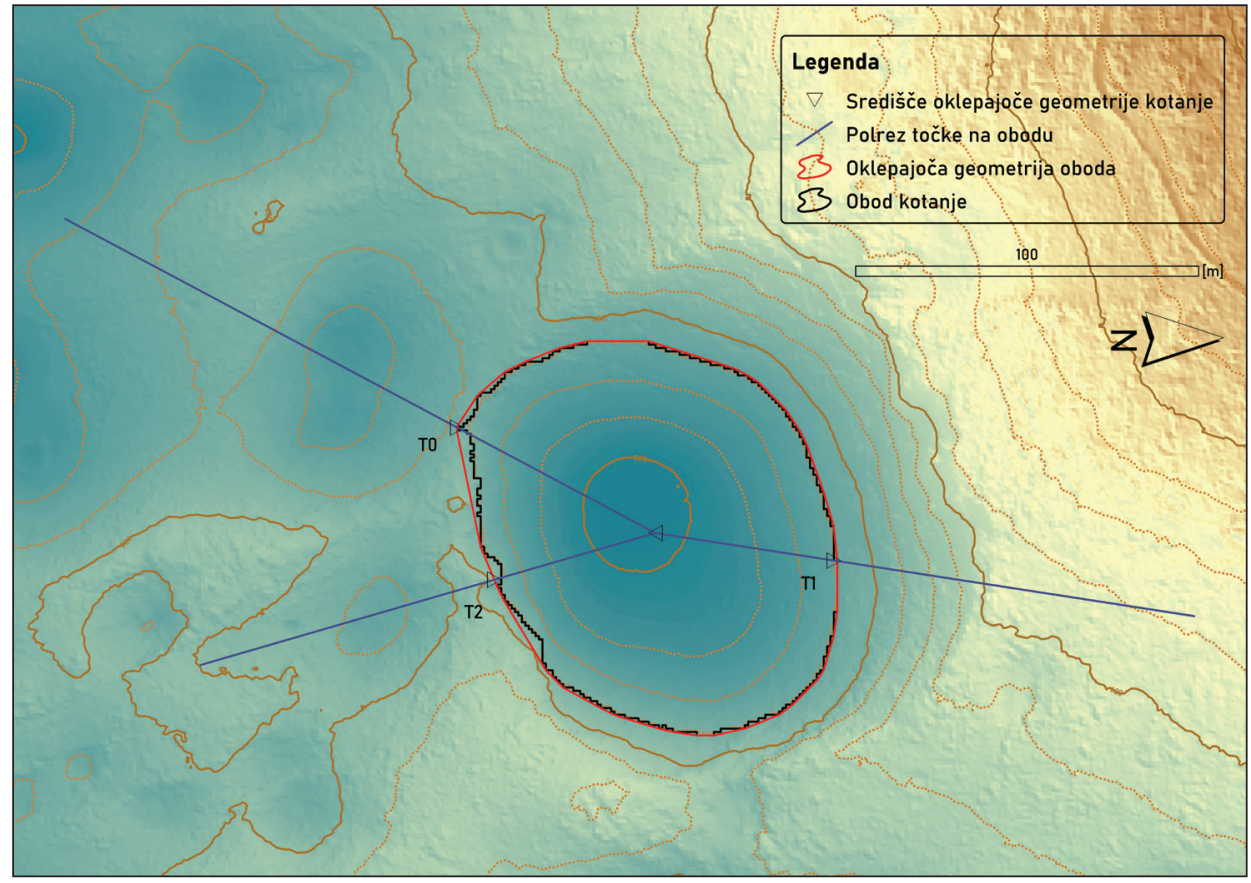

Določitev mesta pregiba pobočja $\mathrm{v}$ kotanjo poteka $\mathrm{z}$ iskanjem vrha funkcije polreza. Vsak polrez kotanje je definiran s centroidom poligona kotanje in vsakim ogliščem poligona kotanje. Zaradi predpostavke, da je dejanski rob kotanje izven poligona hidrološko modelirane kotanje, je vsak polrez podalǰsan za faktor lastne dolžine v smeri lastnega azimuta. Ob daljici polreza poizvemo nadmorske višine vhodnega DMV na vsako enoto njegove ločljivosti ter rezultate izrišemo na grafu. Iz slike je razvidno, da polrezi v smeri naraščanja nadmorskih višin pobočja, na katerem je kotanja, nimajo vrha, torej jim ne 
moremo določiti točke pregiba pobočja $\mathrm{v}$ kotanjo (slika 4). Zato nadmorske višine ob polrezu transformiramo s pomočjo premice linearne regresije. Po metodi najmanjših kvadratov izračunamo koeficient in konstanto premice, ki najbolje opisuje vse višine ob polrezu. Linearne napovedi višin ob polrezu odštejemo od dejanskih višin polreza ter pobočju odstranimo trend. Ostane le še krivulja, ki opisuje del polreza pod premico linearne regresije (dno kotanje) in del krivulje nad isto premico (pregib pobočja). S tem pregibe $\mathrm{v}$ pobočjih, ki $\mathrm{v}$ izvornem polrezu nimajo vrha, spremenimo $\mathrm{v}$ konveksne vrhove s pozitivnimi vrednostmi. Na transformiranih podatkih poiščemo vrhove vzpetin, prvi zaznan vrh določimo kot točko pregiba pobočja v kotanjo. Pri tem nas v prvi vrsti zanimajo izraziti vrhovi funkcije. Kljub transformaciji podatkov nekateri polrezi ne izkazujejo izrazitih vrhov, zato vpeljemo parameter prominence. Krivuljo polreza zato ponavljajoče obdelujemo $\mathrm{z}$ vsakokrat za polovico manjšim parametrom, dokler ne določimo vrha oziroma dokler vrednost parametra ni tako blizu ničle, da nima več pomena. $\mathrm{V}$ tem primeru polrez nima vrha ter je izpuščen iz obdelave.

Slika 4: Prikaz nadmorskih višin ob vzorčnih polrezih izbrane kotanje s pripadajočimi linearnimi projekcijami ter vrhovi polrezov (zgoraj) in razlike med višinami polreza ter njihovimi projekcijami oziroma polrez z odstranjenim trendom (spodaj).
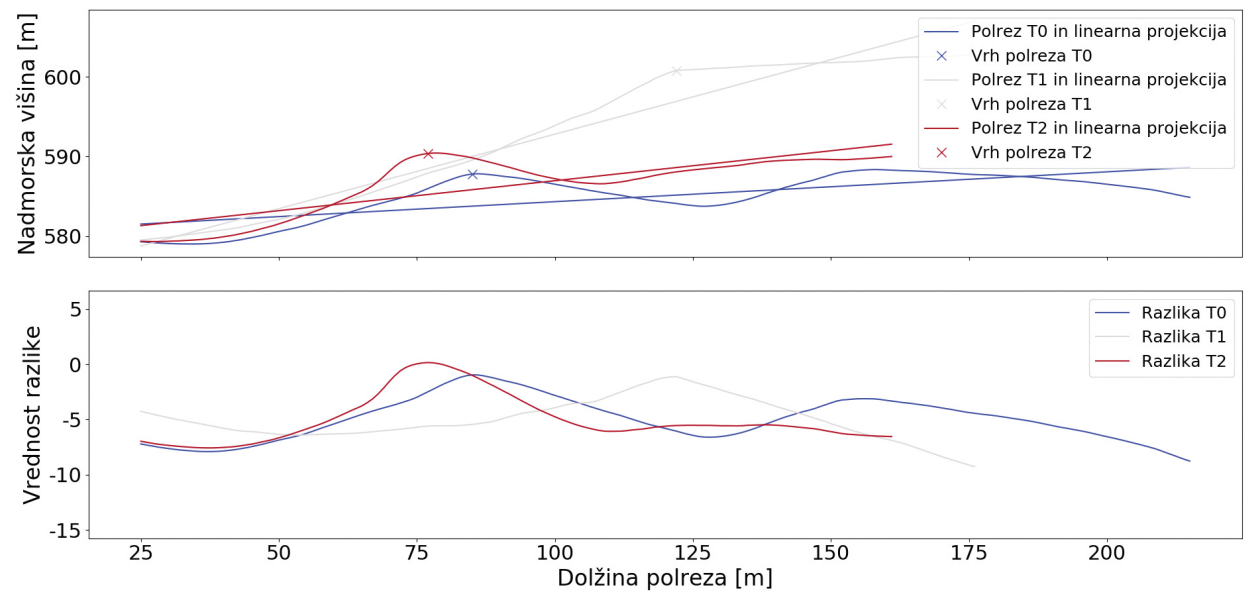

Analiza je zaključena z izračunom koordinate vrha transformirane funkcije polreza. Koordinato dodamo na seznam koordinat $\mathrm{v}$ prilagojeni geometriji, zaključimo obroč ter odpravimo morebitne večje anomalije $\mathrm{v}$ prilagojenem obodu s ponovnim izračunom konveksne ovojnice geometrije. Prilagojen obod zapišemo v nov vektorski sloj poligonov.

Slika 3 prikazuje kotanjo, ki smo jo uporabili pri razvoju metode, in konveksno ovojnico ter vzorčne polreze. Nadmorske višine ob polrezih so prikazane na sliki 4 . Vzorčni polrezi prikazujejo tri značilne oblike. Polrez T0 poteka skozi najnižjo točko 
oboda ter po prehodu seka sosednjo kotanjo. Krivulja polreza ima torej dva vrhova, izbran je prvi, ki bi bil zaznan tudi, če bi vrhove iskali na netransformiranih podatkih. Polrez T1 je primer polreza brez vrha. Vrh tega polreza bi lahko določili, če bi dolžino polreza bistveno podaljšali do pregiba pobočja. Polrez T2 je tipičen polrez z enim vrhom, ki pa leži na višji nadmorski višini, kot je višina T0. Graf (slika 4) prikazuje polreze $\mathrm{z}$ odstranjenim trendom in izrazite vrhove, ki se ob tem pojavijo, ter vizualizira nujnost transformacije podatkov pri obdelavi polrezov tipa T1.

Prilagojene obode kotanj smo vizualno primerjali z obodi hidrološko modeliranih kotanj in kvantitativno primerjavo lastnosti dolžine oboda, površine poligona ter njegove podolgovatosti. Rezultati analize so predstavljeni v naslednjem poglavju.

\section{REZULTATI}

Na obravnavanem območju smo uporabili razvito metodo ter omejili pet kotanj prvega reda. Najprej smo kotanje omejili z uporabo hidrološkega modeliranja ter izdelali sloj izhodiščnih kotanj za nadaljnjo analizo. Vse izbrane kotanje ležijo na bolj ali manj strmih pobočjih ter imajo izrazito nevodoravne obode. Obodi so poleg tega še vertikalno razčlenjeni.

Pri izbranih kotanjah se pojavljajo očitne razlike v obsegu omejene površine glede na uporabljano metodo. Obodi hidrološko modeliranih kotanj sledijo plastnici, ki jo določa nadmorska višina najnižje točke oboda kotanje. Obodi kotanj, omejenih z novo razvito metodo, sledijo pregibom v pobočju ob polrezih, ki jih določajo središče konveksne ovojnice kotanje in njena zgoščena oglišča. Obodi, ki smo jih zaznali z analizo polrezov, praviloma obsegajo večjo površino, najnižja točka oboda pa se dobro ujema z najnižjo točko oboda hidrološko modeliranih kotanj. Kotanje polrezov so bolj razširjene $\mathrm{v}$ smeri naraščanja nadmorskih višin. $\mathrm{V}$ teh smereh večinoma ne moremo zaznati točk obodov zgolj z analizo polrezov samih. Omenjenim polrezom moramo odstraniti trend, da pregibe pretvorimo $\mathrm{v}$ vrhove.

Točke oboda kotanje 0 so ob polrezih razporejene na razdaljah med $12 \mathrm{~m}$ in $33 \mathrm{~m}$, kotanje 1 med $50 \mathrm{~m}$ in $102 \mathrm{~m}$, med $9 \mathrm{~m}$ in $24 \mathrm{~m}$ pri kotanji 2 ter med $19 \mathrm{~m}$ in $49 \mathrm{~m}$ pri kotanji 3. Razpon razdalj točk oboda od središča za kotanjo 4 je med 20 in $50 \mathrm{~m}$. Povprečje oddaljenosti točk oboda od središča je za kotanjo 0 pri hidrološkem modeliranju $14,5 \mathrm{~m}$, modeliranju s polrezi $20,8 \mathrm{~m}$. Razlika znaša $6,3 \mathrm{~m}$. Za kotanjo 1 so te vrednosti enake $55 \mathrm{~m}, 73,5 \mathrm{~m}$ in 18,6 m, za kotanjo $212,4 \mathrm{~m}, 14,5 \mathrm{~m}$ in 2,1 m. Povprečje oddaljenosti točk oboda od središča je za kotanjo 3 pri hidrološkem modeliranju 19,4 m, modeliranju s polrezi $28,7 \mathrm{~m}$. Razlika znaša $9,3 \mathrm{~m}$ in za kotanjo $421,7 \mathrm{~m}, 30,1 \mathrm{~m}$ ter 8,4 m. Razmerja med dolžinami znašajo $1,43,1,33,1,16,1,47$ in 1,38 . Višinski razpon oglišč oboda hidrološko modeliranih kotanj je vedno enak 0 , saj oglišča ležijo na plastnici. Višinski razpon pri modeliranju s polrezi znaša za kotanjo $08,24 \mathrm{~m}$ (med 618,4 $\mathrm{m}$ in 626,6 m), kotanjo $131,04 \mathrm{~m}$ (med 595,2 $\mathrm{m}$ in 626,2 m), kotanjo 25,3 m (med $625 \mathrm{~m}$ 
Slika 5: Primerjava hidrološko modeliranih obodov izbranih kotanj z vrhovi obodov, izračunanih z analizo polrezov (levo), in vsi polrezi izbranih kotanj z izračunanimi vrhovi (desno).

Primerjava obodov kotanj
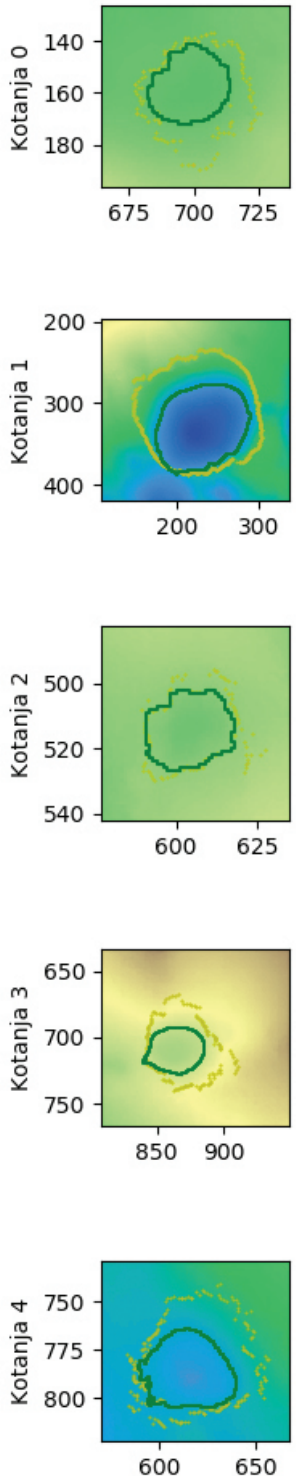
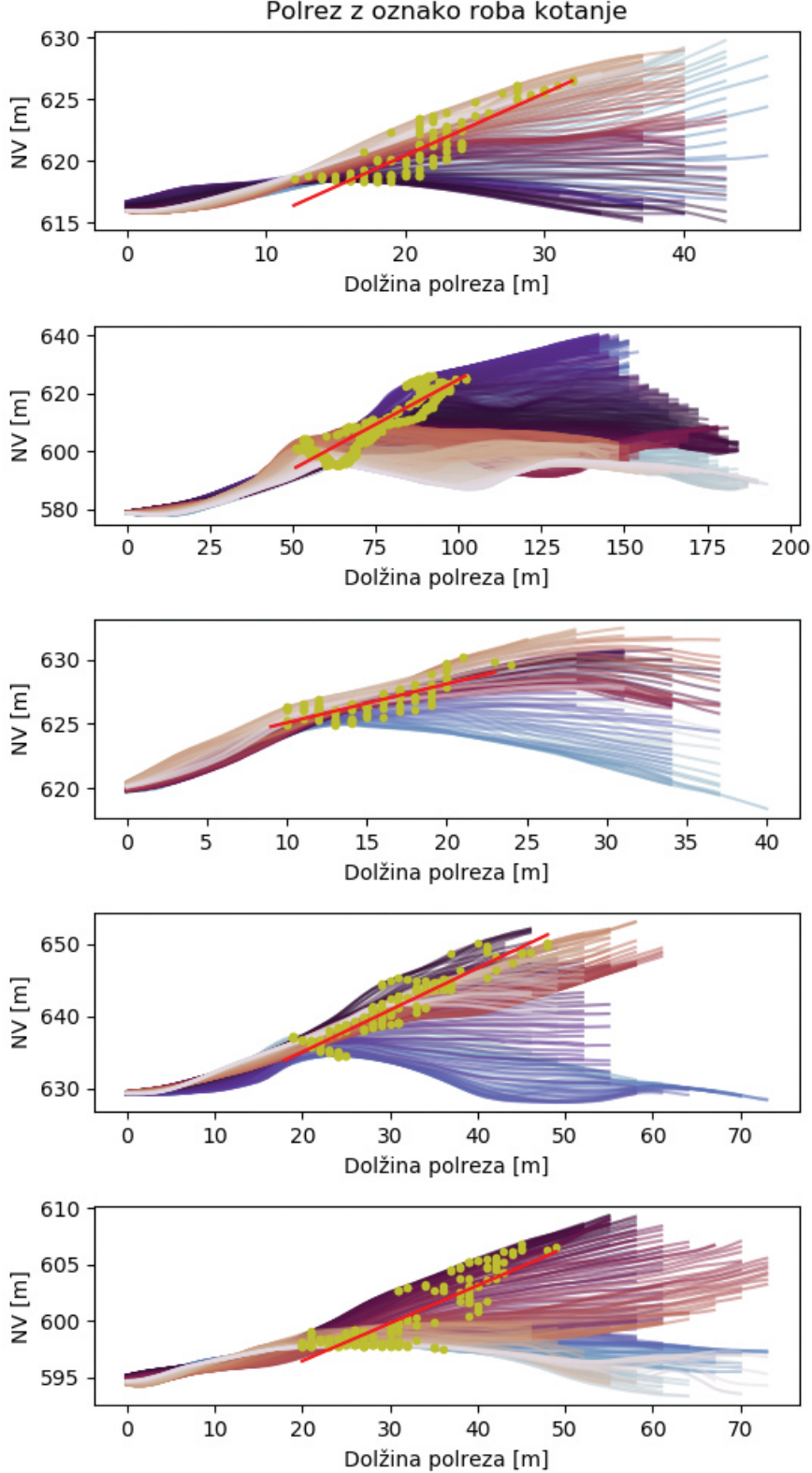
in 630,2 m), kotanjo $315,6 \mathrm{~m}$ (med 634,6 $\mathrm{m}$ in 650,2 $\mathrm{m}$ ) in kotanjo 49,3 $\mathrm{m}$ (med 597,5 $\mathrm{m}$ in $606,9 \mathrm{~m}$ ). Nakloni obodov kotanj znašajo $26,75^{\circ}, 31,77^{\circ}, 16,79^{\circ}, 30,20^{\circ}$ in $18,51^{\circ}$. Koeficienti naklonov premice med razdaljo od središča in nadmorsko višino oboda razkrijejo tudi, da obstaja pozitivna povezava med spremenljivkama. Bolj oddaljena kot je točka na obodu od središča, večjo nadmorsko višino ima.

Kotanje 0, 2 in 4 (slika 5) so navadne vrtače. Prva in druga imata tipično lego v pobočju, kotanja 4 pa ima lego na nizkem grebenu oziroma ga prekinja in deli na dva dela. Pobočji, na katerih ležita prvi dve vrtači, imata blag naklon, zato oboda, modelirana s polrezi, po podolgovatosti in ekscentričnosti ne odstopata bistveno od inicialnih obodov. Enako velja za kotanjo 4, kljub temu da ima obod privzdignjen na dveh straneh.

Pri kotanji 3 (slika 5) gre za zelo netipično vrtačo, ki leži v jarku podobni strukturi, ki je najverjetneje nastala na območju bolj pretrte kamine. Obod, modeliran s polrezi, je zato bistveno bolj podolgovat kot obod hidrološko modelirane vrtače, vendar ne v pričakovani smeri. Obod je razpotegnjen pravokotno na potek jarka. Od najnižje točke poteka navzgor po pregibu oziroma grebenu jarka, dokler polrez seka greben. Ko oddaljenost grebena preseže dolžino polreza, se smer poteka oboda obrne proti središčnici jarka, kjer se obod sklene. Nadmorska višina je na tej točki bistveno nižja od višine na točkah obrata na grebenu.

Kotanja 1 se po morfometričnih in morfogentskih lastnostih razlikuje od ostalih izbranih kotanj. Gre za udornico, ki prav tako kot ostale kotanje leži v pobočju. Poleg tega, da ima pobočje, $v$ katerem leži, večji naklon od ostalih, ima tudi zelo vertikalno razčlenjen oziroma nazobčan obod. Kljub temu z razvito metodo obod zelo dobro zaznamo, saj je pregib med pobočjem in kotanjo zelo izrazit. Slednji obod je po pričakovanjih razpotegnjen po pobočju navzgor ter zajema večjo površino od hidrološko modeliranega. Preglednica 1 prikazuje primerjane lastnosti geometrij, izdelanih po obeh obravnavanih metodah. Dimenzije kotanj, omejenih z metodo polrezov, v vseh primerih presegajo dimenzije svojih inicialnih kotanj. Spremeni se razmerje med dolžinama daljše in krajše osi. Zaradi premajhnega vzorca o zakonitostih te spremembe ne moremo govoriti. Enako velja za spremembo orientacije, ki je povezana s prejšnjim parametrom.

Preglednica 1: Primeriava lastnosti geometrij obodov kotani, modeliranih z analizo polreza (PAK), in hidrološko modeliranih kotani (HMK).

\begin{tabular}{|c|c|c|c|c|c|c|c|c|c|c|}
\hline ID & \multicolumn{2}{|c|}{ Širina [m] } & \multicolumn{2}{|c|}{ Dolžina [m] } & \multicolumn{2}{c|}{ Orientacija $\left[^{\circ}\right]$} & \multicolumn{2}{c|}{ Površina $\left[\mathrm{m}^{2}\right]$} & \multicolumn{2}{c|}{ Obseg [m] } \\
\hline & PAK & HMK & PAK & HMK & PAK & HMK & PAK & HMK & PAK & HMK \\
\hline 0 & 46,83 & 29,40 & 56,40 & 33,62 & 4,70 & 59,60 & 1946,80 & 763,50 & 161,54 & 99,16 \\
\hline 1 & 149,98 & 99,23 & 177,69 & 129,19 & 117,90 & 40,00 & 19579,96 & 9836,50 & 506,43 & 359,24 \\
\hline 2 & 34,09 & 24,60 & 42,26 & 29,41 & 113,60 & 54,70 & 1092,48 & 566,00 & 124,32 & 86,94 \\
\hline 3 & 58,84 & 35,00 & 81,23 & 49,34 & 125,00 & 72,30 & 3673,99 & 1262,50 & 226,50 & 131,20 \\
\hline 4 & 67,12 & 41,00 & 82,28 & 52,63 & 25,30 & 104,30 & 4184,20 & 1624,00 & 238,49 & 148,64 \\
\hline
\end{tabular}


Slika 6: $3 R$ prikazi izbranih kotanj s primerjavo hidrološko modeliranih obodov in obodov, modeliranih z analizo polrezov.

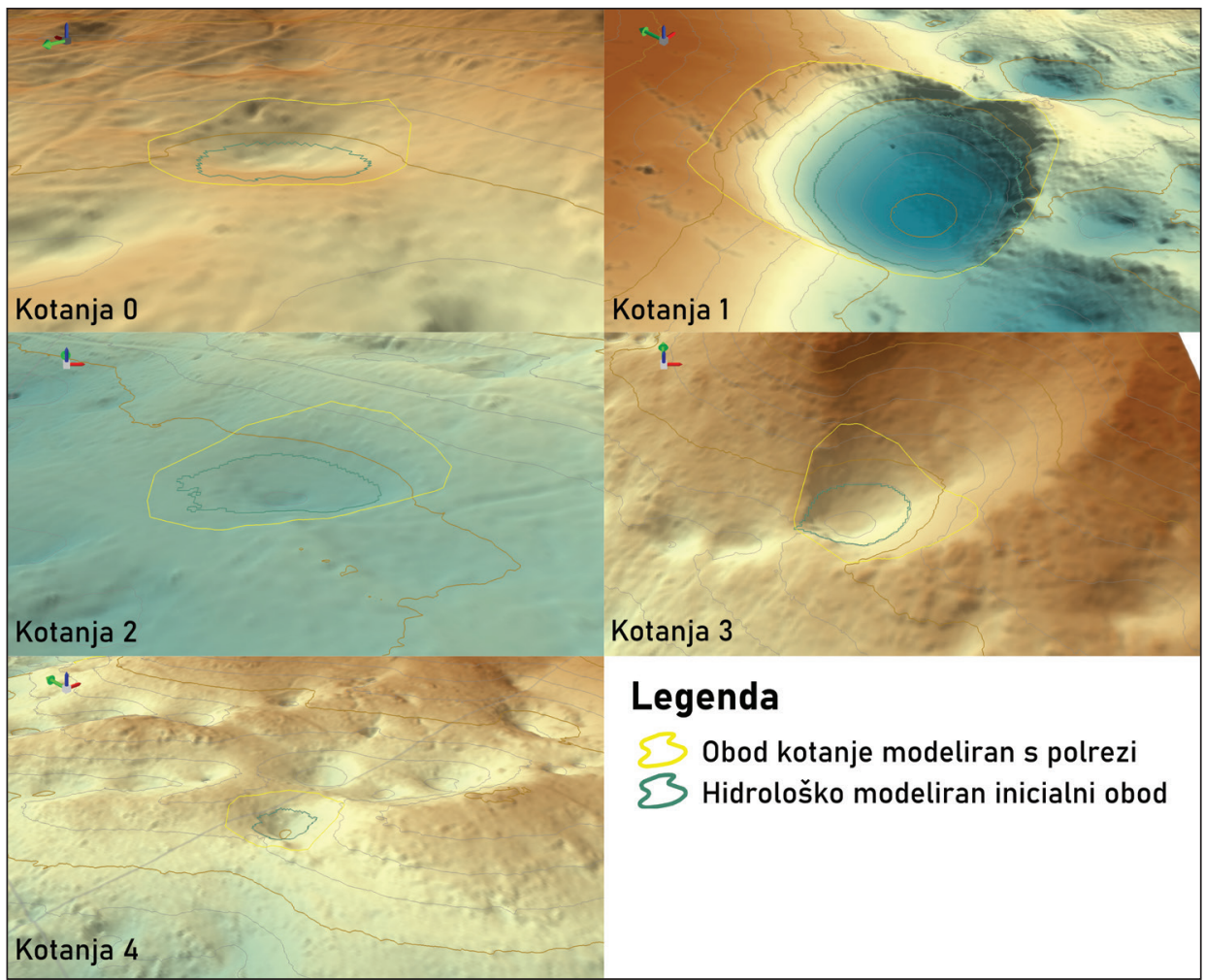

Spremembe morfometričnih lastnosti kotanj ob uporabi drugačne metode omejevanja so pričakovane. Ob predpostavki, ki jo potrjujejo grafični prikazi v tem poglavju, da je metoda omejevanja $\mathrm{z}$ analizo polrezov natančnejša, pa to bistveno spremeni pogled na kotanje. To smo natančneje opredelili in ovrednotili v naslednjem poglavju.

\section{RAZPRAVA}

Primerjava rezultatov zaznavanja oboda izbranih kotanj kaže izrazite razlike v morfometričnih lastnostih teh kotanj. $Z$ vizualno in grafično razlago rezultatov lahko potrdimo, da je novo razvita metoda omejevanja kotanj boljša od metode, ki uporablja samo hidrološko modeliranje. Slednja pa je vseeno nujna, saj z njo zaznamo inicialne obode. Novo razvita metoda rezultate prejšnje zgolj popravi in nadgradi. Razlike morfometričnih lastnosti smo kljub majhnemu vzorcu strnili v preglednici 1. Rezultati kažejo na to, 
da se ob uporabi nove metode morfometrične lastnosti kotanj bistveno spremenijo. To vodi k zaključku, da bomo morali rezultate nekaterih prejšnjih raziskav ponovno ovrednotiti ter spremeniti podatke o morfometriji samodejno prepoznanih kraških kotanj.

Rezultate osnovne metode zaznavanja kotanj (3.1 Hidrološko modeliranje oboda kotanj) smo v začetku ocenili kot neustrezne. S to metodo omejimo zgolj del kotanje, ki ima nadmorske višine nižje od najnižje točke oboda. Uporaba teh obodov kotanj za inicialne obode za analizo polrezov se je izkazala za uspešno, vendar smo med analizo ugotovili še dodatne pomanjkljivosti, ki se odražajo v:

- nazobčanih robovih, ki sledijo robovom rastrskih celic,

- vbočeni geometriji, ki po analizi povzroči nastanek zank v obodu rezultata,

- daljših ravnih odsekih brez oglišč, zaradi česar na teh odsekih ne dobimo dovolj oglišč prilagojenega oboda in s tem manjšo natančnost rezultata.

Navedene pomanjkljivosti oziroma izvore napak v rezultatih odstranimo z izračunom konveksne ovojnice in zgostitvijo oglišč geometrije. S tem odstranimo vbočeno geometrijo ter zagotovimo dovolj točk za definicije polrezov tudi na daljših ravnih odsekih.

Odstranitev linearnega trenda pobočja pretvori pregibe v pobočju v vrhove, ki jih je sorazmerno lahko določiti. Pojavnost polrezov brez vrhov je zelo majhna in nima bistvenega vpliva na rezultat. V kolikor bi pomanjkanje rešitve vplivalo na kvaliteto rezultata, lahko polreze podaljšamo ter s tem povečamo možnost določitve rezultata.

Rezultat analize polrezov so točke, kjer se funkcija polreza oz. linearno transformiranega polreza kotanje obrne navzdol. Ob vsakem polrezu je takih točk lahko več. $\mathrm{Z}$ opisano metodo določimo samo prvo tako točko, na katero naletimo v smeri od središča kotanje navzven. $S$ tem se izognemo zaznavanju točk oboda kotanj višjega reda. Hkrati je to lahko vir napake, saj prvi vrh na funkciji ni nujno pravi in ne leži na dejanskem obodu. $V$ zelo natančnih podatkih o nadmorskih višinah, kot je tudi DMV, izdelan iz lidarskega oblaka točk, ki smo ga uporabili, so vidni tudi antropogeni elementi površja, ki vplivajo na rezultat. Tak primer so na primer suhozidne ograje $\mathrm{v}$ vrtačah. Ob zelo izraziti ograji v vrtači lahko metoda zazna vrh funkcije na vrhu zida in postavi točko oboda na to mesto. Anomalije te vrste večinoma odpravimo z glajenjem funkcije polreza s filtrom povprečja. Za primere, ko ta pristop ne zadostuje, geometriji oboda izračunamo še konveksno ovojnico. Ta zagotovi, da je obod kotanje napet med skrajnimi zaznanimi točkami. S tem se nekoliko oddaljimo od resničnega oboda kotanje vendar odstranimo velike anomalije v njegovem poteku.

Določanje prvega vrha funkcije polreza kot edine in pravilne točke oboda kotanje ima za posledico to, da na ta način lahko omejimo samo kotanje prvega reda. To so kotanje, ki ne vsebujejo drugih, manjših kotanj, lahko pa so same gnezdene v večjih kotanjah. Pri nekaterih raziskavah in analizah je lahko zaželeno zaznavanje tudi kotanj višjih redov. $Z$ opisano metodo je mogoče tudi to. Zaznavo obodov kotanj višjih redov dosežemo tako, da $v$ postopku analize polrezov kot inicialne uporabimo poligone kotanj višjih redov v kombinaciji z DMV, ki ima primerno zapolnjene kotanje nižjih redov.

Glede na rezultate omejenega števila poskusov lahko zaključimo, da uporaba 
opisane metode da zadovoljive rezultate. Dovoljujemo izjeme v obliki robnih primerov, ki bodo obravnavani v nadaljnjem razvoju.

\section{SKLEP}

Prispevek obravnava problematiko zaznavanja kotanj v vrednostih rastrskih prostorskih podatkov. Osredotočili smo se na kotanje na DMV, ki ustrezajo definiciji kraških kotanj - vrtač in udornic. V obeh primerih gre za zaprte konkavne oblike na kraškem površju. Morfometrična analiza oblike teh kotanj se uporablja pri interpretaciji razvoja kraškega površja. Zaradi velike gostote pojava na kraškem površju obstajajo potrebe po razvoju samodejne računalniške metode, s katero bi na DMV prepoznali obode kotanj na večji površini. Tovrstni pristopi so bili razviti in opisani v več delih, vendar z njimi ne dobimo dovolj natančnih rezultatov. Pristopi v veliki meri ne upoštevajo variabilnosti v nadmorskih višinah obodov posameznih kotanj. Pristopi kot obod kotanje obravnavajo najvišjo sklenjeno plastnico ali plastnico, ki povezuje točke z nadmorsko višino najnižje točke oboda. Oba pristopa delujeta samo delno, saj podcenita površino kotanj, ki se nahajajo na pobočjih. Zaznavanje s povprečevanjem DMV s konvolucijskimi filtri različnih oblik je močno odvisno od homogenosti obravnavanih oblik območja in izbire primernih parametrov. Kljub temu, da pristop bolje obravnava kotanje na pobočjih, rezultat tudi ob optimalnih parametrih vselej podceni površino kotanje.

Omenjene pomanjkljivosti pri zaznavanju kotanj na pobočjih in razčlenjenih obodov kotanj so nas spodbudile k razvoju nove metode, ki kotanje obravnava na do sedaj edinstven način. Podlaga za naše delo je bila objava Šušteršiča (1984), ki je ugotavljal zakonitosti oblik pobočij vrtač s pomočjo polrezov. S primerjavo polrezov, ki jih definirajo središče kotanje in posamezne točke na obodu, smo prišli do zaključka, da lahko posamezen polrez obravnavamo na podoben način, kot poteka obravnava podatkov časovnih vrst. Na funkciji višin ob polrezu poiščemo vrhove funkcije ter koordinate te točke zapišemo v poligon oboda kotanj. Vsak polrez ne izkazuje nujno roba kotanje kot vrh funkcije, temveč zgolj kot pregib s spremembo naklona. Zato polrez razdelimo na dva pojava: trend in anomalijo. Trend je v našem primeru povprečen naklon pobočja ali linearna funkcija oddaljenosti od središča kotanje in nadmorske višine. Anomalija je del funkcije, ki predstavlja kotanjo. Razlika funkcije višin polreza in njene linearne projekcije pretvori pregibe v vrhove ter tako omogoči določitev roba kotanje.

Pristop smo preverili na petih različnih kraških kotanjah Podgrajskega podolja. Rezultati analize so v večini primerov zadovoljivi in metodo ocenjujemo kot primerno za novo opredelitev morfometrije kraških kotanj. 


\section{Literatura in viri}

Bauer, C., 2015. Analysis of dolines using multiple methods applied to airborne laser scanning data. Geomorphology, 250, str. 78-88. DOI: 10.1016/j.geomorph.2015.08.015.

Doctor, D. H., Young, J. A., 2013. An evaluation of automated GIS tools for delineating karst sinkholes and closed depressions from 1-meter lidar-derived digital elevation data. $13^{\text {th }}$ Sinkhole Conference, NCKRI Symposium 2, NCKRI, str. 449-458. DOI: $10.5038 / 9780979542275.1156$.

Ford, D. C., Williams, P. W., 2007. Karst hydrogeology and geomorphology. Chichester: John Wiley \& Sons. DOI: 10.1002/9781118684986.

Gabrovšek, F., Stepišnik, U., 2011. On the formation of collapse dolines: A modelling perspective. Geomorphology, 134, 1-2, str. 23-31. DOI: 10.1016/j.geomorph.2011.06.007.

Grlj, A., Grigillo, D., 2014. Uporaba digitalnega modela višin in satelitskega posnetka RapidEye za zaznavanje kraških kotanj in brezstropih jam Podgorskega krasa. Dela, 42, str. 129-147. DOI: 10.4312/dela.42.129-147.

Guimarães, R. F., de Carvalho Júnior, O. A., de Souza Martins, E., Ferreira de Carvalho, A. P., Trancoso Gomes, R. A., 2005. Detection of karst depression by raster image in the Bambui Group, Brazil. V: Ehlers, M., Michel, U. (ur.). SPIE Proceedings, 5983: Remote sensing for environmental monitoring, GIS applications, and geology V. DOI: 10.1117/12.627741.

Krevs, M., 1992. Iskanje lokalnih reliefnih ekstremov na DMR. Geografski vestnik, 64, str. 205-218.

Liang, F., Du, Y., 2013. An automated method to extract typical karst landform entities from contour lines on topographic maps. Geomorphometry, 2013, str. 71-74.

Lidar ARSO. 2014. URL:http://gis.arso.gov.si/evode/profile.aspx?id=atlas_voda_Lidar@Arso (citirano 24.6.2020).

Mihevc, R., 2014. Kraške vrtače Dinarskega krasa. Diplomsko delo. Ljubljana: Univerza v Ljubljani, Fakulteta za matematiko in fiziko, Oddelek za fiziko.

Novljan, Ž., 2019. Vrtače na pobočjih. Magistrsko delo. Ljubljana: Univerza v Ljubljani, Filozofska fakulteta, Oddelek za geografijo.

Obu, J., 2011. Prepoznavanje kraških kotanj na podlagi digitalnega modela višin. Diplomsko delo. Ljubljana: Univerza v Ljubljani, Filozofska fakulteta, Oddelek za geografijo.

Podobnikar, T., Možina, P., 2008. Analiza oblik površja z uporabo lokalnega okna. V: Perko, D. (ur.). Geografski informacijski sistemi v Sloveniji 2007-2008. Ljubljana: Založba ZRC, str. 29-39. DOI: 10.3986/9789612545420.

Rahimi, M., Alexander, E. C., 2013. Locating sinkholes in lidar coverage of a glaciofluvial karst, Winona county, MN. V: Land, L., Doctor, H. D., Stephenson, J. B. (ur.). Sinkholes and the engineering and environmental impacts of karst. Carlsbad: National Cave and Karst Research Institute, str. 469-480. 
Sauro, U., 2012. Closed depressions in karst areas. V: Culver, W. B., White, D. C. (ur.). Encyclopedia of caves (Second edition). Amsterdam: Academic Press, str. 140-155. DOI: 10.1016 / B978-0-12-383832-2.00133-X.

Stepišnik, U., 2015. The problem of dissolution doline definition. Dela, 43, str. 129147. DOI: $10.4312 /$ dela.43.2.29-40.

Stepišnik, U., 2017. Dinarski kras: plitvi kras Zgornje Pivke. Ljubljana: Znanstvena založba Filozofske fakultete.

Sweeting, M. M., 1972. Karst landforms. London: Macmillan.

Šušteršič, F., 1984. Metoda morfometrije in računalniške obdelave vrtač. Acta Carsologica, 13, str. 79-98.

Šušteršič, F., 1986. Zaprte kraške globeli, problematika interpretacije in kartografskega prikaza. Acta Carsologica, 14/15, str. 89-98.

Telbisz, T., Latos, T., Deak, M., Szekely, B., Koma, S., Standovar, T., 2016. The advantage of lidar digital terrain models in doline morphometry compared to topographic map based datasets - Aggtelek karst (Hungary) as an example. Acta Carsologica, 45,1 , str. $5-18$.

Vrviščar, B., 2016. Geološka karta kraškega ozemlja nad jamo Medvedjak na Matarskem podolju. Diplomsko delo. Ljubljana: Univerza v Ljubljani, Filozofska fakulteta, Oddelek za geografijo.

Waltham, A. C., Fookes, P. G., 2003. Engineering classification of karst ground conditions. Quarterly Journal of Engineering Geology and Hydrogeology, 36, str. 101-118.

Waltham, T., Bell, F., Culshaw, M., 2010. Sinkholes and subsidence : Karst and cavernous rocks in engineering and construction. Chichester: Springer, Praxis. DOI: $10.1007 / \mathrm{b} 138363$.

\section{KARST DEPRESSION DELINEATION USING HALF-SECTION ANALYSIS}

\section{Summary}

The article addresses the issue of depression delineation in raster spatial data values. We focused on the depressions on the DEM (Digital Elevation Model), which meet the definition of karst depressions - sinkholes and dolines. In both cases, they are closed concave forms on the karst surface. Morphometric analysis of the shape of these basins is used in the interpretation of the development of the karst surface. Due to the high density of the phenomenon on the karst surface, there is a need to develop an automatic computer method that would identify the perimeter of the depressions on larger study areas. Such approaches have been developed and described in several publications, but we do not obtain sufficiently accurate results with them. Approaches 
largely fail to consider the variability in the altitudes of the circumferences of individual depressions. Some approaches consider the highest closed contour, some the contour that connects the points with the altitude of the lowest circumferential point as the depression border. Both approaches work only in part as they underestimate the surface area of the depressions that are located on the slopes. Detection by averaging DMV with convolutional filters of different shapes strongly depends on the homogeneity of the depressions of the study area and the choice of suitable parameters. Despite the fact that the approach better treats depressions on slopes, the result always underestimates the surface of the depression even with optimal parameters.

These shortcomings in the detection of depressions on the slopes and the depressions with vertically variable perimeter have prompted us to develop a new method that treats depressions in a hitherto unique way. The basis for our work was the publication of Šušteršič (1984), who determined the laws of the shapes of sinkhole slopes with the help of half-sections. By comparing the half-sections defined by the center of the depression and the individual points on the circumference, we came to the conclusion that an individual half-section can be treated in a similar way as the processing of time series data. We aim to detect the peak vertices of the function of the heights along the half-section, and write the coordinates of this point in the polygon representing the perimeter of the depression. Each half-section does not necessarily exhibit the edge of the depression as the apex of the function but merely as a fold with a change in its inclination. Therefore, the half-section is divided into two phenomena: trend and anomaly. The trend in our case is the average slope inclination or a linear function of the distance from the center of the depression and altitude. The anomaly is part of the function that represents the depression. The differences in the function of the heights of the half-cut and its linear projection convert the folds into apexes and thus make it possible to determine the edge of the depression.

We tested the approach on five different karst depressions of the Podgorski Kras. The results of the analysis are in most cases satisfactory and the method is assessed as suitable for a new definition of the morphometry of karst depressions.

(Translated by the author) 